\title{
The Canadian Scene
}

\author{
By Gerald Pratley \\ Spring 1995 Issue of KINEMA
}

At Canada's main film festivals Canadian films have their own showcases: Panorama Canada at Montréal's World Film Festival, Perspective Canada at the Toronto International Film Festival (no longer called Festival of Festivals), Canadian Images at the Vancouver International Film Festival and the Canadian section at Halifax's Atlantic Film. As the summers pass these special programmes bring on high hopes of whole-hearted rejoicing in finding among the almost fifty new feature-length films at least a substantial number to make us quietly proud of what our filmmakers have accomplished in showing audiences here and abroad what it means to be Canadian.

Regretfully, with a sense of loss over what might have been one writes of disappointment rather than the excitement of discovery. Paul Donovan's Paint Cans introduces a character early in the story who matterof-factly mentions that "Canadians can't make films." The audience laughs, as though in agreement, and it is not surprising then to find by the time the picture ends that while Donovan certainly knows how to make films his strong points are not satire and comedy. This adaptation of his novel about the shortcomings of our funding agencies, principally Telefilm and the Ontario Film Development Corporation (OFDC) and some of the bureaucrats who run them, is hit and miss much of the way. It has two quietly effective performances by Chas Lawther and Nigel Bennett whose dialogue rings true, a disappointingly over-played father by Don Franks, and a silly romance set within a visit to Cannes that was certainly not filmed at festival time. ln the book, the agencies and the trade paper are given their proper names but for no apparent reason disguised in the film, weakening the impact and realism of the whole. The touch is too heavy, the score of little help. An overly-enthusiastic young reviewer in a Toronto paper described Paint Cans as the film "the industry is dreading." This statement is much funnier than the film. The trade will be quite unperturbed by it and the public is little interested in the Canadian filmmakers' funding difficulties and those who create them. The same reviewer wrote that "as a result of this picture Donovan will never make another film" meaning that the granting bodies in this attempted satire will refuse him further assistance. They have not, he is working on another film, and one day the determined Donovan will make the film we have been waiting for.

Moving on to the West Coast much was expected from Charles Wilkinson's Max (not to be confused with all the other Max's made here recently). This is an uneven story of an intense father-love for a son with an incurable disorder. The father, played by the talented and valiant R.H. Thomson (who has been this way before in Defy Gravity) begins a frenzied mission to break away from the fast-paced materialistic life he and his family have been living. Without consulting his wife, convincingly played by Denise Crosby, who is quite properly confused and emotionally upset by this abrupt change in her life, he sells up everything seemingly overnight and moves to the clean country air of the mountainous north.

This is all very well, but as depicted here not at all believable. A struggle appears to have taken place between director-writer and the producer as to whether this social study should be a serious drama of the valid issues raised or a sentimental over-blown melodrama. The latter wins and even the concerned Thomson loses control of his character. The director's son, who plays Max, emerges as the most natural element in the story, and yes, he does get well.

Then we have Whale Music, Richard Lewis's interpretation of Paul Quarrington's dream-like novel about a former rock musician living a life of hallucinations in a neglected mansion along the coast of British Columbia while attempting to compose music to soothe the whales. A young girl, a pretty face with a vocabulary limited to four-letter vulgarities, enters his solitary existence and not unexpectedly changes it for the better. Vic Sarin's photography is everything one expects from him and Maury Chaykin, with some charm, creates an immense whale-like presence. As for the whales, they wisely stayed away.

Turning to Québec, the results are not much better this time around. Andre Forcier's Wind from Wyoming is an even more discouraging Imaginary Tale than the last one: a group of thoroughly unpleasant people leading useless lives meet in an uneven mix of fantasy, whimsy and attempted comedy, a stew of crude sexual 
behaviours. The only genuine moment of black humour is the scene of the priest, in his army uniform from the last war, supervising the nuns who are unknowingly digging their own graves. But to link the whole with the work of Buñuel as some reviews have done is absurd bearing in mind that Buñuel was a master in revealing the absurdity of human nature.

In A Hero's Life, the inspiring Micheline Lanctôt goes sadly awry in a seldom convincing and quite pointless memoir carrying us from World War I to the present through the lives of a mother, her daughter and granddaughter. The main thread holding them together is the presence of a German officer, a POW ln rural Québec, with whom the mother falls in love. It is possible to interpret the behaviour and emotions, the myths and memories of the family, then and now, in the light of Québécois sensibilities relating to their isolationist attitudes and resentments during the War. In many instances honesty is lost in ambiguity and the filmmaker herself seems to have become confused in answers and recollections. The wartime period is not entirely convincing.

From the past we look into the future in Robert Morin's Windigo, a mock piece of cinema- journalism based on recent clashes between native peoples and the establishment. An uprising has broken out a few years hence. Political expediency, idealism and deception are hopelessly mixed with media manipulation among poorly drawn characters and improbable events. Native people, meaning those who were here before the rest of us are the subject of Bruce McDonald's Dance Me Outside taken from stories by W.P. Kinsella. Ten years in the planning by Norman Jewison, so it is said, this picture finally comes to the screen as a loosely-stitched jumble of episodes and subplots, undeveloped characters and settings perpetuating the portrayal of Indians as a mostly shiftless, unlearned lot. We seldom care about these individuals, and the final fade-out suggests that this comedy-drama larded with violence should be taken as a bit of a teenage Hollywood romp.

Gary Ledbetter's Henry and Verlin is also country-bound we know not where and chronicles with a certain warmth and understanding the friendship between a mildly retarded young boy (Keegan McIntosh) and his childlike uncle (Gary Farmer), a happy relationship until tongues start wagging about its "unnatural aspects." Simply stated and played it is more likeable and honest than many of its more expensive companions among this season's releases. Margot Kidder turns up with a wooden leg and makes the most of her role as an outspoken voice of reason.

Sensible but slight is Mina Shum's Double Happiness, a portrait of a Chinese family in Vancouver and the conflict between generations, made watchable by Sandra Oh's bright and determined performance in keeping tedium at bay. Among other movies on the festival circuit are two filmed plays on sensitive issues: Cynthia Roberts' Last Supper with Ken McDougall playing a terminally-ill dancer who choreographs his death; and Linda Griffiths' astutely written The Darling Family, directed by Alan Zweig; a middle-aged couple come to understand their true feelings for each other. Somewhat overlooked under the thunder of the front-runners is Jane Thompson's Coming of Age, an understanding, intimate portrait of a woman facing up to life after the death of her husband.

Continuing the rounds from Cannes is Atom Egoyan's Exotica, much heralded and praised by critics here and abroad, and doing very well at specialised cinemas where patrons go to the box-office and ask for "two tickets for Erotica." A bizarre combination of sex, sin and guilt in a more coherent narrative than usual, the story strands still end up going nowhere except to audiences who find needless obscurity somehow satisfying. Finding his way among the sub-plots is a tax collector who has lost his daughter and seeks solace with a young girl resembling her in a sex-hall specialising in "lap-dancing." Again, Egoyan's narrative tends to be superficial, his characters cold and flat. At the Toronto-City Awards at the Toronto Festival Egoyan won First Prize. He generously handed over his $\$ 5,000$ cheque to Mina Shum among joy and self-congratulation all round!

Shunted out of sight unfortunately is Charles Biname's Chilli's Blue, with Roy Dupuis and Lucie Laurier, a sixties romance, sad yet often funny, set in a snow-bound railway station. Also given short-shrift is Charles Massot's Kabloonak, an imaginative and affecting recreation of Robert Flaherty's pioneer visit to the Arctic to film Nanook of the North, with Charles Dance giving a convincing portrayal of Flaherty. It is interesting to contemplate in this 100th Anniversary Year of the Cinema how far we have come: in this co-production with France and Russia it took a crew of over eighty to make a film about Flaherty -- who made his film alone! But Peter Mettler could take a lesson from it: his magical photography of a train trip to Churchill 
to photograph the aurora borealis in Picture of Light is all but blotted out in a monotonous, simplistic and overlength existentialist off-screen meditation. The Anglo-Canadian co-production, Camilla, directed by Deepa Mehta, is a tedious tale not knowing what it's all about. It's saving grace, as critics are anxious to point out, is the penultimate performance of Jessica Tandy.

As for Brigitte Berman's The Circle Game, Jeremy Podeswa's Eclipse, Gregory Wild's Highway of Heartache, Bruce LaBruce's Super 8, Mike Hoolboom's Valentine's Day, Judith Doyle's Wasaga, it is a kindness to say nothing more.

Conversations overheard at Festival Receptions and worth passing on: Regarding the limited vocabulary of many of our films -- "Is there to be no surcease from the stream of scatological exclamations our screenwriters and sub-title writers (or could it be producers and directors) unleash upon us?"; On what is a film festival: "An event where hundreds of people stampede and wait in line to see movies most of them would never think of attending when opening in regular cinemas"; Andrew Sarris, the distinguished American critic (a panelist at Montréal's festival): "Why is it that Australia has repeatedly succeeded with its films and Canada has not?; "Vancouver is the place to be. We have thirty films in production right now." "You mean Canadian films?" "No, American, what's the difference? We're working."

\section{Fade Out}

Festival time is the occasion to bring out the over-zealous nationalistic supporters of our cinema who have never learned the rudiments of the business of film. Describing all Canadian movies as being "idyllic", the biggest obstacle to their acclamation by a public desperate to see this "visual uprising" is according to them, the "lack of distribution." If they read the credits in the programme books they will see that few are without distributors: Alliance, Cineplex-Odeon, Astral, Malofilm, and others, carry most of them. What they mean, as company representatives have frequently pointed out at one trade forum after another, is lack of exhibition due to the reluctance of the circuit cinemas to show them. But that was the past; these days few Canadian films do not receive specialised exhibition by the circuits or independent cinemas. It seldom seems to cross the minds of the believers however, that too many of our filmmakers indulge themselves with the taxpayers money in the making of films the public has little interest in seeing.

\section{Author Information}

Gerald PRATLEY, OC, LLD, started his career as film critic with the CBC. In 1969, he founded the Ontario Film Institute which he directed until 1990. He has written several books and numerous articles on film, including Torn Sprockets, a history of Canadian cinema. He taught Film History in universities in Toronto and Waterloo, Canada and holds three honorary degrees from Canadian and US universities.

Gerald A. Pratley (1923-2011) was born and educated in London, England, and came to Canada in 1946. He started working in Toronto for the $\mathrm{CBC}$ as a scriptwriter. He was drawn toward working in motion pictures, and became, in 1948, the CBC's first film critic and commentator.

Gerald Pratley broadcast three programmes a week, Pratley at the Movies, The Movie Scene, Music From the Films, and others, until 1975. During this time he also became the first post-war chairman of the Toronto Film Society, chairman of the Toronto and District Film Council and co-founder of the A-G-E Film Society and correspondent for international magazines such as Films and Filming, Film In Review, Variety, Hollywood Quarterly and International Film Guide. During the 1950s he wrote for Canadian Film Weekly and Canadian Film Digest.

He became known as a speaker on all aspects of motion picture art and industry, and was invited to teach film history at the University of Toronto, York University, University of Waterloo, Seneca College and Ryerson Polytechnical University, with individual lectures being given at many other Canadian and US universities and colleges. He has served as a member of various judging panels of competitions and festivals, being one of the members of the first Canadian Film Awards in 1949.

From 1970 to 1975 he was the director of the Stratford (Ontario) International Film Festival, and from 1969 to 1976 he was Chairman of the International Jury of the Canadian Film Awards. He has attended all the world's 
leading festivals of film, and in particular, for 30 years, the Cannes Festival as CBC correspondent. He has written six books, The Films of Frankenheimer: Forty Years in Film; The Cinema of John Frankenheimer; The Cinema of Otto Preminger; The Cinema of David Lean; The Cinema of John Huston, and Torn Sprockets, a history of the Canadian cinema.

Gerald Pratley has served on the Advisory Boards of the film departments of Ryerson Polytechnical University and Humber College, and as a member of the programme committee of TV Ontario. In 1968 he became the founder-director of the Ontario Film Institute of the Province of Ontario, an organization which has distinguished itself in archival holdings and public service and is known since 1990 as the Cinematheque of Ontario. He taught Film History courses at the Department of Film and Photography, Ryerson Polytechnic University, Toronto and the University of Waterloo.

In 1984, Gerald Pratley was made a Member of the Order of Canada and in 2003 Officer of the Order of Canada for his service to Canada through film appreciation. He holds Honorary Degrees in Letters and Fine Arts from York and Waterloo Universities (Ont., Canada) and Bowling Green State University (Ohio, USA).

In 2002, Gerald Pratley received a Special Genie Award from the Academy of Canadian Cinema \& Television in recognition of his lifelong dedication to the promotion and his exceptional support of Canadian cinema.

He died on 14 March 2011 in Ontario, Canada. 